Mitra, R (2006) "Living a body Myth - Performing a Body Reality" Post Colonial Theatres Feminist Review, Vol 84, Issue 1, 2006

This extract is taken from the author's original manuscript and has been reproduced with kind permission of Palgrave Macmillan. The definitive published version of this extracr may be found at www.palgrave-journals.com

\title{
Living a Body Myth, Performing a Body Reality: Reclaiming the Corporeality and Sexuality of the Indian Female Dancer
}

\author{
Royona Mitra \\ Drama Department \\ University of Wolverhampton
}

\begin{abstract}
This paper investigates the dilemma that has been projected upon Indian female dancers' bodies by contemporary Indian audiences when female desire occupies the centrality of a performance, projecting the female body as sexual, articulate and independent of the discipline and propriety of classicism. The hostility and discomfort towards the expression of female desire and sexuality in performance by the Kolkata (Calcutta) audience demonstrates a socio-culturally specific, postcolonial and nationalist codification of corporeal aesthetics and female sexuality. Using the frameworks of the Indian nationalist construction of womanhood and chaste postcolonial sensibilities of femininity as the basis for this dilemma, this paper adopts Victor Turner's notions of liminal and liminoid phenomenon and Brechtian defamiliarisation technique as a feminist strategy to construct a framework within which the contemporary Indian dancer can reclaim her sexuality in performance. To investigate the nature of this complex nationalist trope of chaste Indian womanhood, and to analyse the audience's reception of a performance that attempts to subvert this trope by placing agency on the female body as sexual, I locate my argument in the
\end{abstract}


discussion of The Silk Route: Memory of a Journey by Kinaetma Theatre, UK which was performed in Kolkata in August 2004.

Key words: Dance \& Nationalism, Dance \& Culture, Indian Post-Colonial Art, Gender and Sexuality in Indian Dance

The contemporary Indian female dancer is constantly challenged by the historicity of her existence and the progressive demands of her art. On the one hand she adheres to the nationalist trope of Indian womanhood, which historically constructed the classical dancer's body and sexuality as chaste. We see this in the early twentieth century construction of Bharatnatyam as a nationalist art created to cleanse, purify, and regulate 'the erotic and base' practice of Sadir dance of the devadasi tradition which historically lent social and sexual agency to these women, their art and their bodies. On the other hand, now a globalised identity, the contemporary Indian female dancer is additionally exposed to performance vocabularies outside of classicism that enable subversion of the nationalist body politics in reclamation of her corporeality. This paper explores the painful duality as lived experience of the contemporary Indian female dancer. It discusses the dancer's subversive attempt to locate her sexuality as central to the performance by means of a vulnerable and erratic body through the analysis of The Silk Route: Memory of a Journey, a performance by Kinaetma Theatre, UK. It further investigates Kinaetma's use of the Indian female dancer's body as a site of resistance to nationalist discourse, against the hostile criticism of post-colonial audience reception in contemporary India that has deliberately 
constructed and monitored the Indian female dancer as technically virtuoso but lacking the ability to express desire or sexuality. For this reason, my paper begins with an anecdotal account of the performance and most importantly the reception of The Silk Route in Kolkata, India.

In August 2004, I conducted an intercultural dance-theatre project in Kolkata, India as part of Kinaetma Theatre, UK. ${ }^{1}$ Funded and hosted by the British Council, ${ }^{2}$ Kolkata, this project led the participants through three weeks of workshops, culminating in a devised performance, The Silk Route: Memory of a Journey. The departure point for this project was Italo Calvino's Invisible Cities, a rich and provocative rendition of Marco Polo's travels through Asia that explores at its very heart the issues of diasporic existence, and experiences and tensions of cultural displacement and belonging. ${ }^{3}$ The Silk Route: Memory of a Journey was delivered as a promenade site specific performance in the sprawling grounds of an old colonial country club ${ }^{4}$ in the heart of south Kolkata. As the audience traversed through a metaphoric re-creation of Polo's journey, they encountered images of desire, despair, hope, hopelessness and trapped memories through the successive cities of 'Desire', 'Despair', 'Innocence', 'Memories' and 'Reflection' that constituted the different segments of The Silk Route, inspired by Calvino's rendition of Polo's encounters. The year before, Kinaetma carried out its first British Council funded project in Kolkata. Using the same participants, we had created The Changing Room, an adaptation from selected tales of Ovid's Metamorphoses staged in a proscenium arch theatre. We therefore shared with the participants a continuing aesthetic, artistic and social investment, transferring Kinaetma's ethos to their work. We further recognised their wanting to move beyond their own classical parameters of Bharatnatyam, Kathak and Odissi, by either significantly subverting their use of classical idioms or immersing themselves within contact improvisation. 
Working as choreographer for both The Changing Room and Silk Route: Memory of a Journey, I sensed in Ovid and Calvino respectively the innate desire and eroticism embedded in their texts. Female sexuality and its powerful imagery was evocatively present in both Metamorphoses and Invisible Cities. I was keen to physicalise these attributes in the visual performance language that we developed in collaboration with our participants. We wanted to introduce our performers to physical vocabularies and corporeal aesthetics of contemporary western performance practices. We also wanted our audience to experience and confront the eroticism within the texts in an honest way. To achieve this, I introduced the western vocabulary of contact improvisation ${ }^{5}$ onto the Indian performers' bodies. The use of contact based choreography culminated in several intense moments of physical contact and intimacy on stage, implicitly suggesting desire. On encountering these moments, the audience's response was as passionate as it was varied. While some engaged with the content and form of our work, a majority of the audience found it unsettling and controversial to witness intimacy and touch between the performers. Bikram Ghosh, one of our performers recollects this extreme range of responses The Silk Route encountered,

There wasn't a single coherent response to The Silk Route but a number of responses. Some liked it, some didn't, and some were indifferent. However, those who liked the production, liked it a lot and those who didn't, didn't like it at all; so, there were extreme reactions in either case. (Email received 31 January 2006)

While many of the audience members disapproved of the action or even walked out of the performance, uttering exclamations such as, 'utter filth', 'shameless behaviour' and 'this is 
deeply offensive', the journalists' reports interestingly noted the potential novelty of the form and the audience's disapproval of it. Reshmi Sengupta from The Telegraph wrote, $[\ldots]$ there were those who found the body movements of the performers quite uncomfortable $[\ldots . .$.$] the movements were carefree and intimate, often bordering on the$ erotic[...]The ease and uninhibited expressions of the young performers - hugging, embracing and caressing - sprung from the conviction they had in their emotions. (Friday 1 October 2004)

Those who were disturbed by our placement of the sexualised body at the centre of the performance vocabulary mostly articulated the same concern: how did we have the right to depict openly such vulgarity on stage by imposing such westernized vocabularies onto Indian performers' bodies, particularly 'Indian’ female bodies? ${ }^{6}$ And so, our carefully crafted, physically demanding and visually dynamic moments of contact improvisation were reduced to profanity in the minds of our Kolkata audience.

At this point, I must locate myself in the discourse I am setting up. I trained as an Indian classical and contemporary dancer in Kolkata, India where I grew up. I then moved to the UK in 1997 to study western performance practices. Fascinated by the empowering, dynamic and fluid nature of the genre, I chose to specialize in physical theatre. So, for the last nine years I have been simultaneously embodying two completely diverse performance vocabularies, and constantly shift between the two in my own practice. ${ }^{7}$ I also live and work as an academic in the UK. This position between 'doing' and 'articulating doing,' enables me to comment analytically on the audience who encountered Kinaetma's work and disapproved deeply of the depiction of female desire and eroticism within the performance. 
Let me briefly extrapolate for the purpose of this essay, the constituency of the audience we encountered for both The Changing Room and The Silk Route: Memory of a Journey. In Kolkata, events hosted by the British Council attract a very specific target audience. These events are further designated and limited to attendance 'by invitation only'. So, the nature of the audience from one British Council event to another remains largely unchanged. In the case of the Silk Route, the audience were additionally and "primarily members of the upper echelons of Kolkata society; the so-called educated but certainly wealthy classes of Kolkata, members of the Tollygunge Club, an institution which encourages an isolationist experience for those who can afford it' (Ghosh, email received 31 January 2006). Thus the British Council patrons and therefore the audience may be summed up as the 'comprador' class, a post-colonial term referring to the bourgeoisie and English-educated elite within a post-independent society, who have exchanged roles with and embodied the sensibilities of the white colonialists on their departure (Ashcroft, Griffths \& Tiffin 1988). Our comprador class audience consisted of a cross section of the privileged and influential communities of Kolkata mainly representing Bengalis, Punjabis and Marwaris, and therefore a largely Hindu constituency. The significance of their religious identity will be clarified shortly.

To analyse our audience's hostile response to the representation of female desire and eroticism in the work, I want to indicate two points of reference. Firstly, it is important to briefly recapitulate the ritualistic and sexualised status of the pre-colonial female dancer within the devadasi tradition of south India and her consequent construction and re-inscription as the 'classical dancer ${ }^{8}$ within the colonial, postcolonial and nationalist trope of chaste Indian womanhood. In 
being designated the national dance of India, the Bharatnatyam dancer promoted the pure, abstinent and devotional image of the Hindu protectorate, shunning her ritualistic and sexually empowering roots. Secondly, I want to draw attention to the politically significant and potent time period of 2001 to 2004 within Indian politics, during which Hindu nationalism was marking out its territory and sowing its seed within the Hindu psyche through the implementation of the Hindutva ${ }^{9}$ ideology. Dr. Vandana Shiva comments, 2002 witnessed the total messing up of the Indian identity. On the one hand we saw 'Hindutva' in ascendancy.... on the other we read our Prime Minister's...musings, suggesting that 'Hindutva' was the same as Bharateeyata... Indianness in all its diversity and multiplicity.”( http://www.navdanya.org/articles/being_india.htm, accessed 26 November 2005).

Thus, fifty years on, since independence the Hindu-isation project characterized by dualism and exclusion of the 'other' had mythically returned to haunt the nation, shaking the secular identity of the nation to the core. In 2004 elections, the BJP and its Hindutva ideology lost to the Congress party, raising questions about its future and sustainability of the Hindu-isation project. In reality however, it continues to gain power in regional pockets around the country even if the central government rejects its exclusionary practices, and attempts to reinstate a secular nation. It is during these unstable years of the overt reclamation of the Hindu identity as pure, abstinent and pristine, that Kinaetma visited Kolkata and encountered the criticism and hostility of its largely Hindu audience at the two performance events.

At this point, a brief historical overview of the Indian female dancer becomes pertinent. In a culture where it is almost impossible to distinguish between religious and social customs, 
Hinduism and its arts, specifically dance are intrinsically linked. Kalpana Ram affirms this view and says, "Historically, Indian dance never occurs as an isolated, separate practice, but has been integrated into a much larger framework that encompasses...narrative and ritual" (2000: 6). Rooted in spirituality and ritual, dance in India was nurtured as a metaphor for Lord Shiva's perpetuation of the cosmos. ${ }^{10}$ Dance was thus advocated as an integral part of the rituals that were carried out within temples through most of India.. In the Tamil region, Sadir, 'the solo, feminine and graceful variant of the classical tradition' (Srinivasan 1985: 1869) and the ritualistic precursor of present day Bharatnatyam was practiced within the precincts of the temple walls. The dancers occupied an indispensable status, as without their presence and participation, these religious rites could not be performed. Called devadasis, or 'female servants of the gods', these temple dancers were looked upon as the human surrogate of Parvati the Mother Goddess. Varadpande writes of the devadasi, 'In her ritualistic functions, she is connected with "the ancient cult of mothergoddess"' (1987: 165). Sofia Diaz affirms this view, writing that, "Attention would be brought to the performance as an active offering to the divine. The dancer would be recognized as a goddess ... when dancing' (2003: 15).

These women were dedicated to the service of the deity in the temple and regarded as his bride. The devadasis also became custodians of the art of Sadir and were influential in defining the aesthetics of the art form. Kersenboom comments on the mixed symbolism of the status of the devadasi within Hinduism and says that the 'devadasi herself is a very expressive semiotic unit signifying the mythical-aesthetic-cum-ritual object residing in the collective consciousness of Hindu tradition' (1987: xvi). ${ }^{11}$ 
The ritualistic status of the devadasi system and its power to transform the female dancer through the rites of passage into the nityasumangali or the 'forever blessed' can be explained by Victor Turner's notion of liminality (1982). Derived from the root word limen in Latin meaning threshold, the term liminality was used by early $20^{\text {th }}$ century anthropologist Arnbold van Gennep to describe social rituals and customs that accompany the middle phase of the rites of passage, the first one being separation (pre-liminal) and the final stage being reaggregation (post-liminal). Turner borrowed the concept of liminality from van Gennep and believed that in most ritualistic practice in pre-industrial societies ${ }^{12}$, the middle phase of the liminal provides an anti-structural space of flux within which unlicensed acts are legitimately allowed to unfold. Representing the transitional state of instability that often pervades rituals, to paraphrase Colin Turnbull (1990), liminality is a timeless state of being, of 'holiness', through which transitions and transformations from the state of 'normality' to a heightened state of being occurs. Turner continues to say that before entering the liminal phase the individual undergoing the ritual of transformation is separated from others not entering the ritual thereby 'demarcating sacred spacetime from profane or secular space-time' (Turner 1982: 24). At the end of the process, the individual is once again allowed to re-aggregate with society, within which their newly transformed status is acknowledged and revered. Turner suggests that liminality, or the notion of working between the threshold of human instinct and human rationale is woven into the very fabric of traditional societies and is a part of their every day existence. Applying this model of liminality to the devadasi tradition in India, the liminal nature of the ritual from its pre-liminal to its post-liminal phase becomes apparent. Furthermore, attaining the status nitya sumangali through the rites of passage ceremony would allow the devadasi to be re-integrated within the 
social system as an indispensable and revered entity invited for her auspicious presence to dance and sing at social festivals such as weddings and births.

In the Tamil region of South India, this liminal practice of the devadasi tradition and the dance of Sadir evidently flourished from approximately the $6^{\text {th }}$ and $7^{\text {th }}$ centuries AD right up until the middle of the $19^{\text {th }}$ century. However, this was soon to be contested. From the late $19^{\text {th }}$ century, several social and political circumstances began to rock the status of the female dancer within Sadir. The accumulative imposition of colonial morals, followed by the birth of Indian nationalism and its Hindu-isation project, radically challenged and consequently reconfigured the status of the female dancer within the arts.

The gradual entrenchment of Christian colonial morals into the Indian middle class psyche began to challenge and question the transgressive practices of the devadasi within the temples. Unable to accept the close association and co-existence of the sacred and the profane, the British educated middle classes of India, in conjunction with the colonial powers and their Christian sensibilities, started a smear campaign against the surviving devadasi tradition and its liminal status within society, identifying these women as mere prostitutes. Sir William Hunter, a representative of Victorian rule in India, spoke critically of the prevailing devadasi system: Indecent ceremonies disgraced the ritual, and dancing girls with rolling eyes made the modest worshipper blush...The baser feature of the worship which aims at a sensuous realization of God appears in a band of prostitutes who sing and dance alluringly before God's image. (in Varadpande 1987: 179) 
The comprador class Hindus aligned their own beliefs with Hunter's words and launched what came to be known as the Reformist or the Anti-Nautch ${ }^{13}$ Movement from approximately 1890 onwards. Chawla writes, 'The social reform movements, spearheaded by Ram Mohan Roy, Ishwara Chandra Vidyasagar, Govind Ranada...and other prominent social thinkers, questioned the practice of the Devadasi system and pleaded for its abolition' (20). Srinivasan (1985) summarises the consequences of the Anti-Nautch campaign as giving way to two groups of responses: the reformers and the revivalists. The reformists accused the devadasi tradition of prostitution and wanted to abolish the system by emphasizing the moral supremacy of abstinence. The revivalists who felt the importance of preserving the art of Sadir reclaimed the devadasi as a 'nun', holy and devotional in intent and only evoking 'bhakti', the non-sexual devotional rasa of the navrasa through her dance. Srinivasan emphasises that for the revivalists, ' $[\ldots]$ it was the model of the ancient temple dancer as a pure and holy, sexually chaste woman which was stressed in their programme' (1985: 1875). By taking the focus away from the erotic quality of sringara, 'the artistic convention of love between man and woman' (Srinivasan 1985: 1875), the revivalists inscribed into Sadir the pure and 'inward essence' (Srinivasan 1985: 1875) of bhakti, the devotional form of love between human and the divine (Chatterjee 2004). Both parties were keen to cleanse Sadir of any form of sexual expression, while the former abolished the tradition and the latter upheld it as a pure and sacred tradition from the glorious Hindu past. Srinivasan critiques the revival project as, 'a utopian view of the past which is usually an interpretation fitting in with a changed contemporary situation' (2004: 1875) that does not reflect a true image of the past, but a truncated one to fit its purpose. 
Such contrived removal of all traces of liminality and transgressive powers from cultural practices and the arts was influenced by and worked in parallel to the Hindu-isation project of the Indian nationalist movement of the early twentieth century. The need for an 'authentic', 'pure' and therefore unadulterated identity of the Indian nation in response to colonialism came to be recognized. It prompted the use of religion as the basis of achieving this 'pure' identity and advocated the early roots of the Hindutva philosophy that all true Indians were those who were born on the Indian soil and were practicing Hindus. ${ }^{14}$

This Hindu-ised nationalism led to the construction of the image of the nation as the homegrown, pure and chaste Mother India. Andrew Parker believes that,

This trope of nation-as-woman of course depends for its representational efficacy on a particular image of woman as chaste, dutiful...maternal. This idealization of motherhood...would seem to entail the exclusion of all non-reproductively-orientated sexualities from the discourse of the nation. (1992, p 6)

In a previous publication entitled 'Cerebrality: Rewriting Corporeality of a Transcultural Dancer', I have summed up the nationalization project and its close alignment with and construction of the identity and sexuality of the Indian woman as follows:

During the nationalist period and post-independence, India... found the need to desexualise the image of the nation and its people, particularly its women. If one was to metaphorically represent the colonisation of India as rape, or forced entry, then it becomes easier to perceive the desexualisation of the nation as a cleansing process from all things contaminated, foreign, and from all things western; as a process of 
healing wounds inflicted upon the nation. To purify the national identity of all associations with the profane, the image of Mother India as the non-sexual, strong and proactive protectorate rendered through the, 'Myth of Shakti was invoked again and again to compensate for the feeling of powerlessness by making it stand for the motherland...The cultural investment in Indian womanhood, in her voluntary abstinence and purity was made into a national myth.' (Mitra 2005: 171) Thus the construction of the nation as Mother India and the construction of the chaste Indian woman happened in conjunction with each other and were the result of careful deliberation of patriarchal attitudes within the nationalist movement. Within this nationalist trope of the newly cleansed vision of India and Indian womanhood, the liminal practices of the devadasis and her sexually empowered role in society and in art, posed a serious threat to the nationalist project (Ram 2000). However, she could by no means be removed completely as that would mean the instant diminishing of the ancient art form of Sadir. Thus the construction of the chaste Indian woman coincided with the construction and close monitoring of the female dancer whose historicized body and art was re-inscribed to fit the Hindu nationalist agenda. The consequence of the nationalist movement upon the art of dance was thus significant. It led to the reformist construction of the female dancer whose image was strictly controlled by the nationalists who realised that, 'Power, in order to be used, must be controlled' (Zutshit in Chatterjee 2004: 173). Power thus came in the form of a reformist and modernist project undertaken to re-inscribe Sadir into a 'respectable' high art form, by removing from it all traces of the liminal and the eroticism of its past. Bharatnatyam, the national dance of India, with its roots deeply in the devadasi tradition of Sadir was born. The project is mainly attributed to the vision of Rukminee Devi Arundale, a high caste Hindu from a respectable family who occupied an influential role within 
the construction of Bharatnatyam as the classical and national dance of India. Devi, among other Hindu nationalists and reformists believed that somewhere in the historicity of the art, a pure dance form had been contaminated with baser characteristics and needed reformation and cleansing (Stiehl 2004: 8). According to Ananya Chatterjee, Rukminee Devi in effect 'classicalized' and de-eroticized the dance practiced by the devadasis, renamed it Bharat-natyam, and effectively cast it as the primary classical dance of an Indian recovering from the shame and debilitation of years of colonization.” (2004: 142)

Rukminee Devi's process of cleansing Sadir primarily involved the removal of the attribute of sringara, the erotic quality that entrenched the ritualistic practice of the devadasi tradition. Devi succeeded in 'purifying' in a significantly puritanical manner, the baser qualities of Sadir from its tainted association with the devadasi tradition by replacing sringara with bhakti, or devotion. ${ }^{15}$ (Chatterjee 2004) This desexualisation of the art and the dancer mirrored the image of the abstinent and pure Mother India and Indian womanhood constructed by Hindu nationalists. The nationalist project thus appropriated the ancient and erotic tradition of Sadir purely at its aesthetic level and removed it completely from its ritualistic context to transform it into Bharatnatyam, the classical dance of the newly emerging 'respectable' middle class and symbolic of India's 'uncontaminated' Hindu cultural heritage.

In 1937, the Madras Music Academy, created by Rukminini Devi and other influential middle class Hindu nationalists passed a puritan resolution that in order to make dance respectable as public performances before 'respectable' people was a necessity. The dancer was thus removed from the ritualistic confines of the temple walls to the secular and public forum in new 
configuration of the proscenium arch theatre. The proscenium arch establishment was also regarded by the privileged middle class as housing 'respectable' art and entertainment. Dance became the property of this class and Srinivasan astutely observes that since then 'the art has come to be preserved is that very section of Indian society' (1985: 1875). Within this new configuration of audience/performer dynamic, the new Indian dance audience disassociated Bharatnatyam from its ritualistic temple roots and witnessed the art not as an interactive and transformative ritual, but as a 'pure' and crystalised art form that had 'inherited a legacy of the beauty and magnificence' (Chatterjee 2004) of the bygone romanticized Hindu past.

Partha Chatterjee (1999) argues that the problem with nationalism is that it sustains and continues to uphold the legacies and sensibilities of the colonial powers in their attempt to emulate successful models of modern nations. Thus, ironic as it may seem, in their attempt to fight the colonial regime and its sensibilities, on achieving independence, nationalists consequently managed to, 'internalize rather than problematize the Western blueprint in the name of progress [and] modernization' (Radhakrishnan 1992:86). In this construction of the nation, there is no agency for the expression of 'self'/subjectivity as it gets consumed into the collective and nationalist voice of the nation. And as the nation and its identity is represented as abstinent, the expression of sexuality is negated within the nationalist project. This is particularly true of female identity and sexuality within postcolonial India. Mary E John and Janaki Nair ellaborate on the status of woman in modern India:

Women bear the marks, sometimes, violent marks of caste, ethnic and national imaginations. Not only have middle-class, upper caste women been the ground on which questions of modernity and traditions are framed, they are the embodiment of 
the boundaries between licit and illicit forms of sexuality, as well as the guardians of the morality of the nation. (1998: 1)

I argue that this condition of purity has pervaded the construction of the abstinent and asexual female dancer. Emerging through centuries of contested identity and history, Bharatnatyam, identified as the central classical dance of India is regarded as a pristinely aesthetic, highly codified and secular art form. Having been removed from the temples premises, the practice of Indian dance within the proscenium arch setting has lost its ritualistic roots. On a largely generalized but factual basis, contemporary female disciples are not made aware of its ritualistic beginnings in Sadir. Instead, they are expected to follow closely instructions as rendered by their gurus and attempt to emulate them to perfection. Caught in this process of repetition and emulation, there is no place for the dancer's intellectual growth and corporeal expression or a sense of self. Avanthi Meduri writes on the contemporary Indian dancer's dilemma,

The twentieth century performing artist, living in a secular reality, struggles to embrace, emotionally and intellectually, the theoretical ideal that has been set up. If she cannot personally achieve the ideal, she repeats the theory. So theoretician and artist trace the same circle, the figure eight, in which they are both held mutually captive.” (in Stiehl 2004: 9)

The physical space the dancer occupies is also closely defined and monitored. The spinal column through the various classical forms, particularly in Bharatnatyam is held upright and the use of the extended arms marks out a very clear personal space, which is never invaded. Thus, there is no physical contact or any form of intimacy expressed with another dancer. Dance in India is no longer a ritualistic and corporeal embodiment of experience as advocated within the devadasi 
system. It has instead come to represent a highly skilled and visually stunning spectacle representative of a chaste motherland.

Judging from the response to Kinatema Theatre in 2004, the present day British Council invited audience too seems to be heavily inscribed with sensibilities and moralities of a chaste Indian nation and womanhood. This audience rejects eroticism and open expression of physical affection, let alone sexuality in society and considers sex as a functional act, disassociated from desire. On being asked to comment on the audience's discomfort with the sexualised body in performance, Bikram Ghosh recounts,

I did another workshop organised by the British Council, Kolkata in conjunction with their annual school drama festival, workshopped by reputed members of the stage in the city. One of the 'facilitators' ... told us that we shouldn't touch ourselves or each other on stage: she demonstrated by miming hand-grabs and postures where she didn't touch herself and didn't touch anyone else in her action. She said this was necessary because otherwise it restricted movement on stage. Immediately after she mentioned that all girls on stage should wear shorts under their skirts, 'just in case.' Why there is such a controversial link between the body of the performer and their sexuality, I don't know. What I do know is that there are several ridiculous 'rules' that are exercised to make sure that such exploration is not normal. (Email received 31 January 2006)

The practice of dance therefore must shun, through an artificial denial of its history, its sexual, liminal and transgressive roots within ritual and religion. So, when the audiences witness Indian contemporary dancers like Mallika Sarabhai, the late Ranjabati Sircar and Chandralekha (who 
attempt to reconfigure the language of Bharatnatyam by reaching back to its corporeal roots), trying to push the boundaries of 'acceptability' in the newly defined secular space of the theatre by evoking images of sexuality and desire, their response is not too dissimilar to the way they reacted to Kinaetma Theatre's performances. To quote Judith Hanna,

When Chandralekha performs a duet during which she straddles a male dancer whose head appears between her legs, she shocks a middle class audience comfortable in the premise of female subjugation to the male.... Audiences are shocked...because the duet's heterosexual physical contact exceeds the bounds of Indian propriety. (1993: 131)

To quote Chandralekha herself, through this rejection of the tactile and sensorial power of dance, the 'vital link between body and nature, body and work, body and ritual, snaps. Dance becomes, almost totally, a spectacle' (2003: 52).

Located within this theoretical framework, an understanding of the concern that our Kolkata audience voiced towards Kinaetma's work becomes somewhat clearer. By accusing Indian female bodies of exhibiting open vulgarity through their physicality, it is implicitly implied that such physical intimacy would have been acceptable, even expected from female performers who were non-Indian. In being evaluated against the Indian notion of womanhood as pure, abstinent and inexperienced, we had therefore failed the litmus test as we had depicted Indian bodies and identities as sexual and thus aligned them with western values (the very same values that had been rejected vehemently through the grueling construction of the pure and desexualised Indian woman). Anandhi observes this irony in stating that, "the opposition between "desexualized" reproductive bodies as the ideal norm of "respectable" female sexuality and "sexual bodies" as 
its other, representing "immoral" and "disrespectable" sexuality" (1998: 145) clearly privileges reproductive sexuality to any other kind.' Chatterjee affirms this view when she states that in post-independent India, 'women...must sublimate their desires and reduce sexuality to a function of reproduction only' (2004: 173).

Kinaetma had subverted the nationalist trope of the chaste Indian woman. In Kinaetma's cities of 'Desire', 'Innocence', 'Memories' and 'Reflections', audiences had encountered female performers who had used their bodies free of physical restriction and social propriety and made intimate contact with other bodies. Their spines had escaped the upright parameters of classicism and moved through curvatures and spirals, giving into gravity to embrace the floor and other bodies in the space. They had attempted to 'rewrite' most inscriptions upon their bodies to be replaced by expressions of subjectivity, agency and sexuality. And when some audience members had experienced glimpses of the latter, they could not negotiate the novelty of the language and the intellectual demands it had made of them. It was much easier for them to fall back into the nationalist trope of chastity.

It is important to qualify the performance training of the participants we were working with. It would be safe to state that all those who engaged with contact improvisation had their roots within the classical codifications of either Bharatnatyam, or Odissi or Kathak. Initially inhibited by the conscious breaking down of the social codes, they eventually negotiated their physicality to a point where it was liberating. They found within the framework of The Silk Route an escape from the restrictions of classicism and its chaste embodiments of femininity. Classicism also found its place alongside contact work in The Silk Route. In the city of 'Desire', lying on a bed of 
flowers, encircled within burning terracotta pots, I journeyed physically from desire to despair. Juxtaposed against the precision and synchronicity of my fellow dancers' Bharatnatyam vocabulary, my own body moved from the erratic to the dangerous to the erotic, giving into contact with the floor and eventually trying to break through the uncompromising gait of the classical dancers. Eventually, the purity of their classicism pushed me out of the circle in despair, rejecting my unlicensed and erratic physicality amongst their midst. I wanted to evoke in their presence the memory of the female dancer who was once empowered, sexually and corporeally through her art. In the city of 'Reflections', encased in a hall of mirrors, three dancers roamed the space, contained in pristine and crystalised bodies of the Bharatnatyam idiom. Their faces were vacant and ghostlike as remnants of Calvino's City of the Dead. But caught in the repetitive and simple structure of their upright postures, outstretched arms and legs, their bodies spoke a thousand words. Chatterjee theorizes such a condition of extreme beautiful precision and aesthetic perfection of these neo-classical dancers as, 'inextricably entangled with fractures, painful memories and unacknowledged disjunctions.' (2004: 157) It was almost as though they were subconsciously living through the painful rejection of the ritualistic and liminal roots of Sadir, which they were denied.

Some members of the audience were particularly distressed to learn that an Indian woman from Kolkata had choreographed the work. They perceived my apparent 'westernisation' as an obvious departure from my Indian roots and its associated abstinence and morality. In some senses, they viewed me as a stigmatised presence within the work. Our construction of their encounter with erotic imagery from the immediacy of the promenade site-specific environment of The Silk Route: Memory of a Journey was carefully and deliberately framed. In addition, in 
Calvino's provocations through a series of short stories in Invisible Cities was captured the same sense of displacement and dislocation that our performers felt caught between cultures and performance traditions. Invisible Cities, as a starting point became a metaphor for their conditions, plaguing them to come out of their comfort zones, urging and sometimes forcing them to encounter their own insecurities of belonging/non-belonging, comfort/discomfort and familiar/unfamiliar. Edita Marelic writes on Calvino's provocative power in the Invisible Cities through the issues which were close to home with Kinaetma's situation and aesthetics: 'The issues covered in this collection of stories are visitor versus inhabitant, home vs. non-home, outsider vs. insider, foreign languages vs. mother tongue' (http://www.korculainfo.com/marcopolo-korcula-invisible-cities.html, accessed 26 March 2006). As a Company, we wanted our audience to experience a similar sense of discomfort, by initially lulling them into a false sense of security and then, unexpectedly, distancing their experience as far as possible from all sense of familiarity. Ben Chaim theorises the notion of 'distance' to defamiliarise the audience within the theatre experience;

Those qualities that make the object like ourselves (humanization) pull the object towards us; those aspects which distinguish the object from ourselves...push the object away from us. The aesthetic tension between these two opposing tendencies constitutes distance...(in Bennett 1997:16)

In the Silk Route Kinaetma created an unfamiliar world of corporeal language, within a very familiar environment of the club grounds. The audience, mostly consisting of members of the club did not encounter any space that was new to them. Yet, every space they entered was transformed and heightened from their usual experience of it, set alight by the live body's interaction with the spaces. While the dancers' bodies, belonging to the children of fellow club 
members, friends and families were familiar, their physicality revealed the subjects and their desires within. They were as recognizable as they were estranged, living a familiar body myth, but performing a different body reality. 
We wanted to artificially construct a liminal environment, removing the security of the fourth wall, by bringing the audience within a few feet of the live imagery that unfolded before them. We removed the proscenium environment completely and allowed the close proximity of the audience and their apparent discomfort and exposure to the environment to shape the performance language by using direct address and eye contact. Colin Counsel writes of the phenomenon of an audience's disconcerting encounter with the body of 'live performance':

The body of live performance is unique in that...it occupies the same time and space as the audience. ...the live performer's emphatic physical presence has the capacity to remind viewers of the outside of the fiction, juxtaposing the body which is signified, performed, with the real, signifying body of the performer. (2001: 125)

Thus, in sharing the same time and intimate and claustrophobic space with the performers, we had attempted to force the audience to witness a sense of the female dancer's own body, subjectivity and sexuality, in the hope of disrupting any pre-conditioned reception of Kinaetma's work. Kinaetma further wanted to license this unruly, messy, volatile body that behaves in uncontrollable ways to evoke the feminist theorization of the female body that is able to dismantle the gaze of the audience and resist fetishisation by exercising its own agency through rewriting her body (Diamond 1997). Theorizing the importance of the body as a postcolonial subversive tool, Elizabeth Grosz says,

If the body is the specific target of systems of codifications, supervision and constraint, it is also because the body and its energies and capacities exert an uncontrollable, unpredictable threat to a regular, systematic mode of social 
organization. As well as being the site of knowledge-power, the body is thus a site of resistance, for it exerts a recalcitrance, and always entails the possibility of a counter-strategic reinscription, for it is capable of being self-marked, self-represented in alternative ways. (in Gilbert \& Tompkins 1996: 204)

Through choreographic patterns of contact improvisation and pedestrian movement that resisted control and codifications, Kinaetma had consciously enabled the performers' bodies to behave in unpredictable and untamed ways, allowing their bodies to become 'sites of resistance' for achieving alternative modes of expression and self-representation through a corporeally reliant language, instead of the logocentric orientation of naturalistic theatre.

It would also seem that through sub-conscious means, Kinaetma had paid homage to the Brechtian concept of Verfremdungseffekt - the alienation effect of Brecht's epic theatre. By tearing down the fourth wall and creating a mise-en-scene (Pavis 1992) that attempted to defamiliarize the audience from their known environment and the performance language they experienced, we had attempted to make the audience experience the performers and their narratives afresh, from a new and challenged perspective through signs that would enable distance between the audience and the action. To this end, we alternated images of beauty and desire with those of ugliness and despair in order to move beyond a theatre experience that was restricted to the realm of 'naturalism', iconicity and therefore acceptability. Elin Diamond's (1997) discussion on the constructive employment of the Brechtian alienation technique as a tool for empowerment within feminist theatre practice becomes a helpful model through which to analyse Kinaetma's creative strategies. Diamond says, 
If feminist theory sees the body as culturally mapped...Brechtian historisization insists that this body...is a site of struggle and change. If feminist theory is concerned with the multiple and a complex sign of a woman's...historicity, Brechtian theory gives us a way to put that historicity in view - in...theatre. (1997: 52)

As choreographer for The Silk Route, I recognized in this creative strategy of Brechtian defamiliarisation the feminist potential to subvert the nationalist attempt to silence the Indian woman, to enable the female performers to voice their desires through their bodies. By controlling the aesthetics of the space and the performance language very carefully, Kinaetma had created an artificially constructed environment of participatory ritual between the audience and the performers through theatrical strategies and physical technique. My work with Kinaetma in India attempts to reclaim the Indian woman's body and sexuality from the bounds of patriarchal nationalist propriety. I am interested in exploring the conflict between the collective identity of the nation and the individual identity and body of the Indian female performer and her narrative of passionate conflict between tradition and modernity. To use Foster's words, I am interested in exploring in movement,

The body's role in the production of narrative, in the construction of collectivity, in the articulation of the unconscious, in the generation of postcoloniality....in the new relations between history and memory, the aesthetic and the political, the social and the individual. (1996: xv)

Through a succession of artistic choices as scenographer and choreographers of the space and bodies, Kinaetma had attempted to reclaim sexual agency in performance through the expression of desire and the use of physical contact and intimacy with other bodies in the space. Contact 
improvisation had enabled us to ignite a hitherto pre-inscribed and licensed space with explosive moments of articulation of empowered female bodies and identities.

\section{Word Count : 7,173 words (without quotes and footnotes)}

\footnotetext{
${ }^{1}$ Kincetma, an amalgamation of kine which is Greek for movement and atma which is Sanskrit for soul is a UK based alliance of theatre practitioners and academics from Indian and European performance traditions. Kinaetma works between cultures, exploring the embodied phenomena of cultural exchange, identities and myths through imagistic and visceral means. (www.kinaetma.co.uk)
}

${ }^{2}$ The role of the British Council, division of the British High Commission in India is contentious. Established to represent a new, dynamic and a mutually beneficial relationship with the sub-continent since independence, the British Council aims to promote British culture, education and arts within India. Its patrons are significantly limited to the English educated, privileged and metropolitan classes of the country. Kinaetma Theatre, being a UK based theatre company thus fell into the latter category of the arts. This was however before the patrons learnt about the participation of Indian performers within Kinaetma's 'westernized' processes, at which point we entered a different discourse with them.

${ }^{3}$ In Invisible Cities, Calvino paints one fantastical city after another for Polo to describe to Khan in his attempt to capture the essence of these different cites through the eyes of the one and the same, Venice, Polo's roots. Calvino's subtle commentary on the displacement caused by travel and diaspora and belonging and non-belonging is intelligently crafted into arguing that our sense of perception of the 'Other' is always colored by our experience of the known, our self. The Silk Route explored this political insight in letting the participants create cities and experiences as varied as possible.

${ }^{4}$ Tollygunge Club was founded as a recreational country club in 1895 by the British, and continues to represent in spirit and its function, the grandeur of the colonial period and its present decaying glory. For 
Kinaetma, and The Silk Route: Memory of a Journey, the club therefore became an appropriate metaphor for a space that has stood for imposed power structures, cultural exchange and dialogue since the late nineteenth century.

${ }^{5}$ The development of contact improvisation is attributed to Steve Paxton and his generation in America during the 1970's. A reactionary response against the stylisation of American modern dance, contact improvisation explores points of intimate, bodily contact where two or more people share weight between themselves and the floor. It is non-hierarchical and requires continuous and equal participation from each performer. It thus created a new space and vocabulary for social interaction outside the hierarchical structures of choreographers and directors. It is in this context that I encountered contact work in my own physical theatre training in the UK and decided to use this vocabulary to depict eroticism and desire in Kinaetma's work in India.

${ }^{6}$ It becomes difficult to find a specific citation as the designated voice for this collective articulation of criticism, as it was a collection of sources and not one single source that voiced these opinions. These concerns were thrown at Kinaetma and the Indian participants by different members of the audience, ranging from academics to theatre and film critics to parents and families of the ensemble cast. For the purpose of this paper, I therefore paraphrase in my own words the kind of comments that were made regarding the performance.

${ }^{7}$ I explore the phenomenon of embodying such varied performance trainings and the issues of cultural propriety and subjectivity through corporeal and cerebral analysis of this condition in my essay 'Cerebrality: Rewriting Corporeality of a Transcultural Dancer' published in Tanz im Kopf, German Dance Research Yearbook 2005.

${ }^{8}$ To prevent the risk of homogenizing the several regionally distinct classical dance forms under the generic term of 'Indian classical dance', I clarify now that while my essay may bear relevance to historical conditions of several Indian classical dance forms, I am going to focus specifically on tracing 
the history of the Sadir dancer from the southern state of Tamil Nadu and her strategic re-inscription into the secular and pristine status of the Bharatnatyam dancer of the early twentieth century. While I develop this argument in further detail later on in the essay, at this stage I want to remind readers that the crafting of Bharatnatyam as a classical form, occupied a vital place within the nationalist Hindu-isation project.

${ }^{9}$ Hindutva is a word that was coined by Vinayak Damodar Savarkar in the 1920's to connote movements that advocate political Hindu nationalism. Implying 'Hinduness', the term refers specifically to a national identity based around the Hindu religion, excluding anyone not indigenous to the motherland or 'matribhumi'.

${ }^{10}$ In Hindu mythology, Shiva, the Lord of Dance, is responsible for the creation, preservation and destruction of the cosmos through the art of dance. Shiva dances the tandava, the dance of power, proactive-ness, vigour and rage associated with notions of masculinity. Through Goddess Parvati, his consort, Shiva renders the dance of lasya, the soft procreative energy of femininity that promotes grace, sensuality and love - the sacred and sexual female energy and catalyst of procreation that cannot be separated from the body of the Mother Goddess.

${ }^{11}$ I do not intend to reiterate the already existent, rich documentation of the social, political, economic, sexual and aesthetic history of the devadasi, her art and her status in society provided by scholars such as Srinivasan (1985), Kersenboom (1987), Judith Lynn Hanna (1988) and Varadpande (1987) in the last twenty years. Instead I shall use their existing works to foreground a framework within which to carry out my own analysis of the future construction of identity and sexuality of the post-independence female dancer.

${ }^{12}$ I am aware of the critique I invite here by referencing Turner's notion of the liminal as presentational within a preindustrialised context. I want to clarify however, it is not so much the westernized notions of civilization via industrialization that Turner depends on which aids my argument, as the difference he draws between liminal acts as presentational and liminoid acts as representational (Gilbert \& Tompkins 1996). Its usefulness as an analytical framework will become clear as the paper develops. 
13 'Nautch' in itself was a British corruption of the Hindi term 'naach' meaning dance. 'Because femininity had become a correlative to dancing, it came to signal eroticism and loss of masculinity, both threats to the moral health of society. This was the moral logic behind British and comprador class prescriptions against dancing, which put the seal of state power on the stigmatization of women as dancers.' (Mandrakanta Bose 1998: 253)

${ }^{14}$ It was also during this crucial period of Indian history, that the Ramakrishna Mission devised an official ceremony by virtue of which one could convert to Hinduism. Prior to this Hinduism was regarded as a philosophy that one adhered to, and there were no ceremonies to confer the faith upon willing individuals. ${ }^{15}$ In contrast, renowned devadasi Balasaraswati spoke for the importance of sustaining sringara within dance, defining its expression as purely abstract and entirely spiritual and non-carnal. 